\title{
ЦИФРОВІ ОСВІТНІ РЕСУРСИ В ТЕОРІЇ І ПРАКТИЦІ СУЧАСНОЇ ЗАРУБІЖНОÏ ОСВІТИ
}

\author{
Надія Воронова \\ кандидат філософських наук, \\ доцент кафедри культурології, естетики та історії \\ ДВНЗ «Донбаський державний педагогічний університет» \\ м. Слов'янськ, Україна \\ ORCID ID 0000-0001-7957-1655 \\ voronova.ns@ukr.net
}

\begin{abstract}
Анотація. Процеси інформатизації освіти в останні роки пов’язані з їі цифровізацією, усе більшого поширення набуває мобільне та інші види електронного навчання на цифрових пристроях, відбувається певне переформатування електронних освітніх ресурсів, формується нове покоління навчальних засобів - цифрові освітні ресурси (ЦОР) (Digital Learning Resources, DLR). Наразі перевага віддається відкритим освітнім ресурсам, які можуть працювати на будь-якому цифровому пристрої, тобто відкритим цифровим освітнім ресурсам (Open Digital Learning Resources). Вивчення зарубіжного досвіду засвідчує формування й розвиток цифрового освітнього середовища майбутнього покоління (Next Generation of Digital Learning Environment, NGDLE).

Виокремлено й проаналізовано основні функції названого середовища: сумісність та інтеграція, персоналізація, аналітика, співпраця, доступність та універсальний дизайн. Визначено основні складники та функціональні компоненти цифрового освітнього середовища майбутнього покоління для закладів вищої освіти. Доведено, що нове покоління освітніх ресурсів формується внаслідок еволюції традиційних систем управління навчанням (Learning Management Systems, LMS) та їхнє зближення з принципами відкритої освіти і гнучким персональним освітнім середовищем (Personal Learning Environment, PLE).
\end{abstract}

Ключові слова: цифрові освітні ресурси; цифрове освітнє середовище нового покоління; відкрита освіта; відкриті освітні ресурси; відкрита ліцензія.

Постановка проблеми в загальному вигляді. Використання електронних навчальних засобів в останні роки стало досить традиційним явищем у системах освіти України та зарубіжжя. Навчальні засоби (освітні ресурси) наразі мають вигляд онлайн-курсів, мультимедійних підручників, дистанційних курсів, інтерактивних плакатів, презентацій тощо, упровадження яких вимагає відповідних технологій, методик, інноваційних форм і методів, що забезпечують ефективність електронних засобів навчання.

Наразі унормовано документально-правове підгрунтя використання електронних освітніх ресурсів: 2012 року прийнято «Положення про електронні освітні ресурси» (Наказ МОН України № 1060 від 01.10.2012 р.), у якому надано визначення й затверджено різні види електронних освітніх видань (підручник, посібник, веб-сайт тощо) як сучасні навчальні засоби; наказом МОН України № 440 від 02.05.2018 р. затверджено Положення про електронний підручник, у 
якому внормовано вимоги до змісту і структури цього навчального засобу. Ці нормативно-правові документи цілком узгоджуються з Законами України «Про освіту» (2018) та «Про вищу освіту» (2014), Концепцією Нової української школи (2016), а також із концептуальними стратегіями та аджендами (Стратегія розвитку інформаційного суспільства в Україні (2013), Проєкт «Цифрова адженда України - 2020» (2016), зокрема із зарубіжними (Рамкова програма Свропейського Союзу з фінансування науки та інновацій Horizon 2020 тощо), які наголошують на необхідності використання на всіх рівнях освіти якісного електронного навчального контенту та відповідного програмного забезпечення.

Проте в останні роки інформатизація освіти йде шляхом її цифровізації, усе більшого поширення набуває мобільне та інші види електронного навчання, що вимагають використання цифрових пристроїв (планшетів, смартфонів). Тож відбувається певне переформатування електронних освітніх ресурсів, формується нове покоління навчальних засобів - цииррові освітні ресурси (ЦОР) (Digital Learning Resources, DLR) різних видів і форм.

Аналіз останніх досліджень і публікацій. Цифрові освітні ресурси $\epsilon$ сучасним різновидом інформаційних ресурсів, використовуваних в освіті. Як зазначено фахівцями Інституту Новітніх Технологій в Освіті (http://intoedu.com.ua/uk), цифрові освітні ресурси є представленими в електронному вигляді навчально-методичними матеріалами, що вміщують як елементарні об'єкти (текст, малюнок, анімацію, модель), так і складні форми (документ, слайд, презентація, тест, курс) (Цифрові освітні ресурси, n.d.).

Вітчизняна освіта має певні напрацювання в галузі е-навчання, зокрема розроблення електронних навчальних засобів. Це стосується, передусім, електронних (мультимедійних) підручників (програмних педагогічних засобів) для загальноосвітньої школи, які створювалися 2006 - 2009 рр. видавництвом «Нова школа» на основі єдиної електронної оболонки, яка заповнювалася уроками згідно навчальної програми кожної дисципліни. Оболонка дозволяла включати до уроків мультимедійний контент (відео- та аудіо фрагменти, анімацію, фотоматеріали, ілюстраціі), уміщувала методичні матеріали, додаткові інформаційні розділи (глосарій та іменний покажчик) та методичні рекомендації щодо встановлення й застосування. Окремі аналогічні зразки було розроблено для системи вищої освіти, зокрема педагогічні програмні засоби 3 іноземної (англійської) мови для педагогічних ВНЗ.

Усі названі електронні навчальні засоби належать до категорії локальних і потребують певних матеріальних витрат для встановлення на комп'ютері, що обмежує можливості їхнього використання. Поодинокі приклади електронних підручників i посібників із різних навчальних дисциплін створюються ентузіастами е-навчання вищої школи 3 використанням різних програмних оболонок (як локальні навчальні засоби) чи у вигляді вебсайту (для навчання онлайн). У цьому разі про будь-яку системність і комплексність взагалі не йдеться. 
Відзначимо, що на сьогодні питання розроблення електронних навчальних засобів залишається надзвичайно актуальним. Наразі перевага надається відкритим освітнім ресурсам, які можуть працювати на будь-якому цифровому пристрої, тобто відкритим иифровим освітнім ресурсам.

Для вивчення можливостей відкритої освіти доцільно звернутися до зарубіжного досвіду, бо для забезпечення освітніх потреб у різних країнах створено значну кількість електронних освітніх ресурсів, зокрема відкритих цифрових навчальних засобів, курсів, підручників тощо, які можуть бути використані для е-навчання на цифрових пристроях. Серед поширених інформаційно-комунікаційних середовищ відкритої освіти:

1. Open Educational Resources (OER, https://www.oercommons.org/) Відкриті Освітні Ресурси - вебсередовище, що надає доступ до навчальних матеріалів (онлайн-курсів, модулів, підручників, потокового відео, тестів), програмного забезпечення, інших інструментів, матеріалів і методів, що використовуються для підтримки доступу до знань за різними галузями. Крім того, надається можливість для спілкування з педагогами по всьому світу.

2. Coursera (http://www.coursera.org - платформа безкоштовних онлайн курсів (близько 600) із відеолекціями, завданнями й обговоренням на форумах від викладачів провідних університетів світу, 3 можливістю отримати електронний сертифікат після завершення курсу.

3. Academic Earth (http://academicearth.org) - колекція безкоштовних онлайн-курсів із психології, педагогіки, менеджменту тощо, розроблених фахівцями кращих університетів світу.

Для системи вищої освіти, а також для неперервної освіти та освіти впродовж життя розроблено значну кількість онлайн-курсів (більшість із яких $\epsilon$ безкоштовними), відкрито доступ до репозитаріїв відеолекцій та курсів провідних науковців світу: значну кількість відкритих освітніх ресурсів можна знайти в міжнародній навчальній мережі World-lecture-project (http://worldlecture-project.org/), яка надає доступ до повних курсів та відеолекцій із різних наукових галузей від відомих навчальних закладів світу; відеокурси кращих університетів світу пропонує MyEducationKey (http://www.myeducationkey.com) - віртуальний освітній портал, що надає відкритий доступ до навчальних відеолекцій та інших мультимедіа засобів для студентів, учнів і викладачів.

Провідні університети світу мають власні онлайн-платформи, на яких розташовані репозитарії освітніх ресурсів (відеолекції науковців, онлайн курси): вебресурс edX (https://www.edx.org/), заснований Гарвардським університетом i Массачусетським технологічним інститутом; медіацентр Пристонського університету (https://mediacentral.princeton.edu/); аудіовізуальні освітні ресурси Massachusetts Institute of Technology (https://ocw.mit.edu/courses/audio-videocourses/) тощо.

Більшість наведених ресурсів можуть успішно працювати на будь-яких цифрових пристроях (смартфонах, айфонах, планшетах), вони на практиці 
демонструють дієвість принципів відкритої освіти, задекларованих у міжнародних документах (Кейптаунська Декларація відкритої освіти (Тhe Саре Town Open Education Declaration, 2007, http://www.capetowndeclaration.org/); Аналітична записка Сврокомісії «Analysis and mapping of innovative teaching and learning for all through new Technologies and Open Educational Resources in Europe», 2013, https://eur-lex.europa.eu/legalcontent/EN/TXT/PDF/?uri=CELEX:52013SC0341\&from=EN) тощо).

Отже, процеси дигіталізації й відкритості поступово охоплюють увесь освітній простір, входять у всі освітні ланки та набувають нормативно-правового й наукового обгрунтування. Наразі йде чергове оновлення електронних освітніх ресурсів і зарубіжна наука наголошує на необхідності створення нового покоління навчальних засобів, які ввійдуть до цифрового навчального середовища.

Формулювання цілей статті (постановка завдання). Метою статті $\epsilon$ аналіз зарубіжного наукового досвіду з питань цифровізації освіти та створення нового покоління цифрових освітніх ресурсів, які працюють за принципами відкритої освіти.

Методика дослідження. Дослідження проводилося відповідно до плану науково-дослідної роботи кафедри теорії і практики початкової освіти в межах комплексної теми дослідження «Професіоналізм педагога: теоретичні та методичні аспекти» (номер державної реєстрації - 0115U003313) ДВН3 «Донбаський державний педагогічний університет» (м. Слов'янськ).

Результати дослідження. Стрімкий розвиток сучасних інформаційних технології призводить до того, що системи управління навчанням (Learning Management Systems, LMS), або системи дистанційного навчання, що використовуються для розробки, управління та поширення навчальних онлайнматеріалів із забезпеченням спільного доступу та які ще минулого десятиліття відносилися до освітніх інновацій, наразі стали визначати як досить традиційні (через їхнє поширення й технологічну та методичну внормованість).

Науковці М. Браун (M. Brown) (2017), Г. Доббін (G. Dobbin) (2016), M. Линч (M. Lynch) (2018) та ін., які працюють над теоретичним і практичним забезпеченням відкритої освіти (Open Education), фахівці в галузі цифрових i мобільних технологій (Digital \& Mobile Technology) в останній час ведуть мову про більш сучасне покоління освітніх ресурсів, яке вони називають Next Generation of Digital Learning Environment (NGDLE) - цифровим освітнім середовищем наступного покоління.

NGDLE має стати універсальною цифровою навчальною платформою для вчителів та учнів, викладачів і студентів, місцем розташування й надання програм, послуг навчання та інструментів управління навчанням. Програмне забезпечення нового покоління освітніх ресурсів буде концентрувати в одному місці всі необхідні компоненти та реалізовувати такі функції, як подання матеріалів, тестування, управління даними, розклад занять, аналітика навчання, мультимедіа, засоби співпраці та комунікації, інструменти для обміну 
матеріалами та підтримки навчання. Ця платформа має надати підтримку навчальної діяльності як викладачів, так і студентів.

Виділяють п'ять ключових функцій цифрового освітнього середовища наступного покоління (Brown, 2017) (рис. 1):

1. Сумісність та інтеграція (Interoperability and Integration): ділитися даними через платформу.

2. Персоналізація (Personalization): навчальна діяльність для кожного.

3. Аналітика, консультування та оцінювання навчання (Analytics, Advising, and Learning Assessment).

4. Співпраця (Collaboration).

5. Доступність та універсальний дизайн (Accessibility and Universal Design): оптимізований для використання й доступу на різних пристроях.

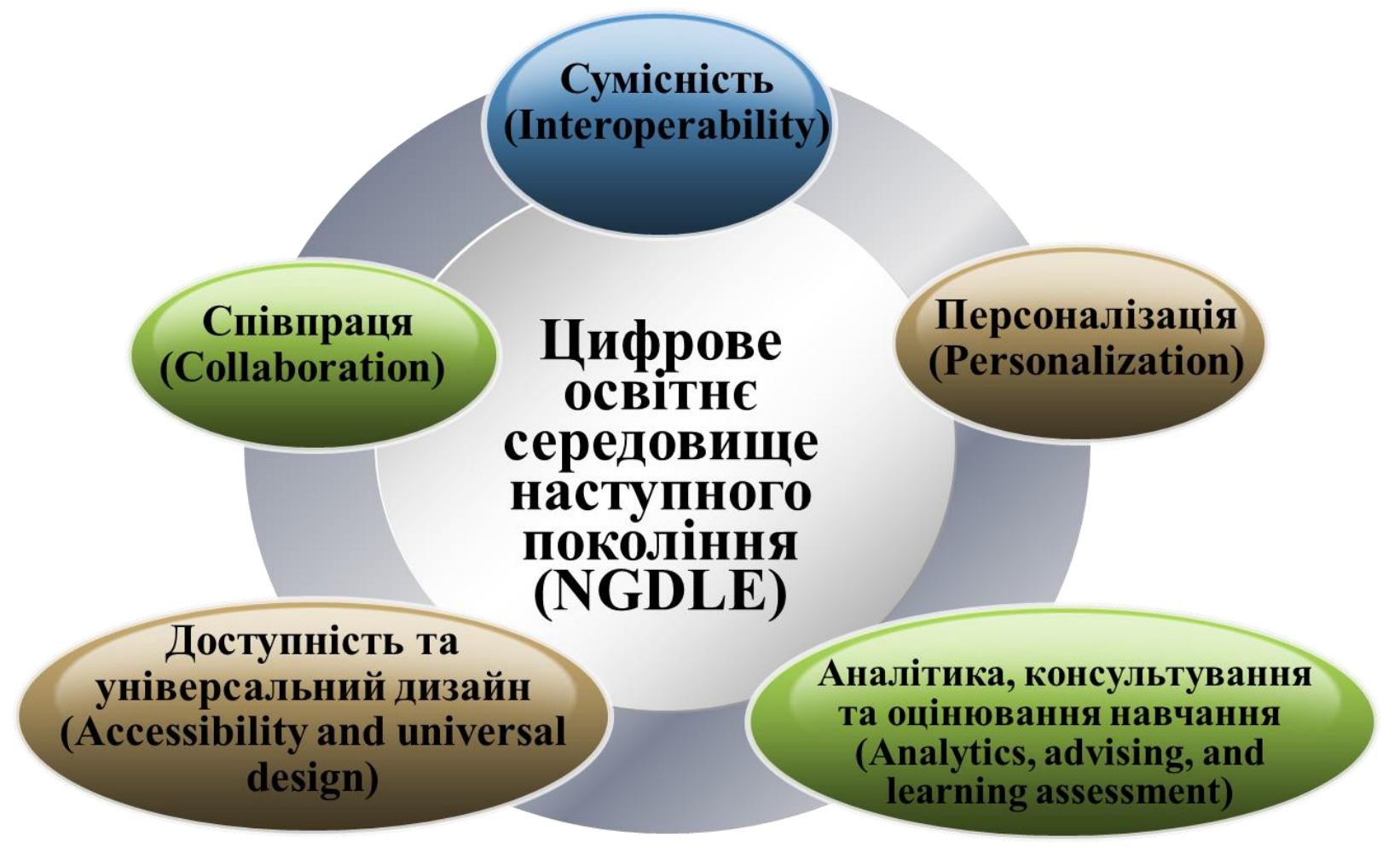

Рис. 1. Ключові функиії иифрового освітнього середовища наступного покоління (NGDLE)

Фахівці університету Міннесоти (Brown, 2017) серед компонентів цифрового освітнього середовища наступного покоління виокремлюють такі:

1. Доставка матеріалів курсу (Course Material Delivery).

2. Навчальна аналітика (Learning Analytics).

3. Відкриття / створення вмісту (Content Discovery / Creation).

4. Інформаційне сховище (Data Warehouse).

5. Інформаційні панелі (Dashboards).

6. Системи управління навчанням (LMS).

7. Програми оцінювання (Assessment Applications). 
8. Системи консультування (Advising Systems).

9. Адаптивні навчальні програми (Adaptive Learning Applications).

10. Соціальні мережі (Social Networking).

11. Компетентнісно орієнтовані навчальні програми (Competency Based Learning Applications).

12. Спеціальні для закладу засоби навчання (College Specific Learning Tools).

Упровадження названого цифрового освітнього середовища розпочалося від 2015 р. у кількох університетах США. Як стверджують учені, NGDLE задумане як певна екосистема - середовище навчання, що складається 3 інструментів навчання та компонентів, що відповідають загальним стандартам. Крім того, це середовище в більшій мірі, ніж попередні навчальні середовища, забезпечує різнобічну підтримку навчання.

Для ефективного функціонування цифрового освітнього середовища розробляється спеціальне програмне забезпечення 3 додатковими розширеннями, що дозволяють швидше налаштовувати ресурси, покращити функціональність користування та підвищити безпеку для захисту даних. Науковці (Goodrum at al., 2019) вказують, що йдеться про нові стандарти взаємодії користувачів з інструментами навчання (Learning Tools Interoperability (LTI) Advantage), які забезпечують інтеграцію навчальних додатків та інструментів у програмі для цифрового навчання. Розроблення нових стандартів (LTI Advantage) пов'язано 3 великою кількістю наявних платформ для енавчання та електронних навчальних ресурсів. Ці стандарти вдосконалюють екосистему цифрового навчання навчального закладу, роблять його інтуїтивним для викладачів, додаткові розширення LTI стандартів забезпечують реалізацію принципу інтеграції ресурсів, додатків та навчальних засобів у курсі (спрощується процедура зарахування на курс, процес вибору та додавання посилань на вміст із зовнішнього джерела при розробці курсу, вдосконалюється оцінювання та зворотний зв'язок). Нові стандарти взаємодії користувачів 3 інструментами навчання (LTI Advantage) повністю відповідають сучасному баченню цифрового навчального середовища (NGDLE).

Фахівці університету м. Утрехт (Нідерланди) М. де Віт (M. de Wit) та Г. ван Домпселер (H. van Dompseler) (2017) виокремлюють та докладно описують функціональні компоненти сучасного цифрового навчального середовища для закладів вищої освіти:

1. Організація навчання або управління навчанням (Organisation of Learning or Learning Management) - чіткий і легкий доступ до змісту та додатків.

2. Цифрове тестування (Digital Testing) 3 метою поліпшення якості тестування й навчання взагалі.

3. Подання та оцінювання завдань (Submission and Assessment of Assignments) - функція, що забезпечує якісну координацію та зворотній зв'язок зі студентами, зокрема перевірка студентських робот на плагіат. 
4. Управління та використання інформації про студентів (Management and Use of Student Information) - управління адміністративними даними студента (зокрема особистими даними), реєстрація відвідуваності занять, оцінювань тощо.

5. Урегулювання розкладу занять (Timetabling).

6. Стажування та підсумкові проекти (Internships and Final Projects) взаємодія між студентом та організацією, у якій проходить стажування; управління контрактами та документами, моніторинг якості стажування.

7. Розробка, управління та обмін навчальними матеріалами (Developing, Managing and Sharing Learning Materials).

8. Підтримка навчального процесу (Education Process Support) розроблення інструментів, які використовуються для моніторингу успішності студентів і надання їм цільового зворотного зв'язку для підтримки процесу навчання.

9. Навчальна аналітика (Learning Analytics).

10. Спілкування (Communication).

11. Співпраця (Collaboration).

12. Мультимедіа (Multimedia).

13. Додаткове вільне програмне забезпечення (Freely Available Applications).

Функціонування цифрового освітнього середовища наступного покоління (NGDLE) не можливе поза принципами Відкритої освіти, тому в зарубіжній науці і останні роки приділяють багато уваги цьому поняттю. Передусім відзначимо декларування багатьма університетами Америки та Європи (першими були Університет Саутгемптона та Масачусетський технологічний інститут) політики Відкритої освіти, тобто підтримки, фінансування, використання відкритих освітніх ресурсів (Open Educational Resources, OER) та практики відкритої освіти (Open Education Practices, OEP). Така політика підтримує розробку відкритих освітніх ресурсів та їхню інтеграцію до навчальних програм, підкреслює життєздатність і цінність засобів відкритої освіти у викладанні та навчанні, допомагає впровадити OER у коледжі та університети. Поступово розвиток відкритої освітньої політики має зробити відкриті освітні ресурси центром освітньої практики.

Відкриті освітні ресурси (OER) є матеріалами для викладання, навчання та досліджень у будь-яких середовищах, вони знаходяться у вільному доступі або випущені за відкритою ліцензією. OER включають у себе доступні в цифровій формі підручники, навчальні плани, навчальні програми, конспекти лекцій, відео, аудіо, програми моделювання, ресурси оцінювання та будь-який інший контент, який використовується в освіті. За необхідності до відкритих освітніх ресурсів належить і друкований контент, виданий за відкритою ліцензією (це необхідно, коли високошвидкісний Інтернет не $\epsilon$ доступним). Користувачі можуть без витрат отримати доступ до відкритих освітніх ресурсів - широкого 
спектра високоякісних і гнучких навчальних матеріалів - використовувати, розповсюджувати і перерозподіляти їх. Викладачі можуть коригувати свій навчальний план для задоволення освітніх потреб та інтересів учнів і співпраці 3 колегами по всьому світу.

Зарубіжні науковці наполягають на деяких юридичних аспектах використання відкритих освітніх ресурсів, вони вважають, що необхідно надавати відкриті ресурси як файли, що можна редагувати, із правовим дозволом на «п’ять R» (Green, Illowsky, Wiley, Ernst, \& Young, 2018):

Retain - зберігати (створювати, володіти та контролювати копії вмісту, зокрема їхнє завантаження, копіювання та зберігання);

Reuse - повторно використовувати (різними способами, наприклад, у класі, на вебсайті або через відео);

Revise - переглядати зі змінами (адаптувати, налаштовувати, модифікувати чи змінювати контент, наприклад, перекладати на іншу мову);

Remix - оновлювати (поєднати оригінальний або перероблений вміст 3 іншим матеріалом, щоб створити щось нове, наприклад, змішування контенту);

Redistribute - перерозподіляти (розповсюджувати копії вихідного вмісту разом із версіями).

Таке вільне та відкрите використання вмісту дозволяють відкриті ліцензії, зокрема Creative Commons, зберігаючи авторське право на роботу, розміщену в вільному доступі.

Про підтримку політики Відкритого доступу до освіти заявляють i українські університети (Києво-Могилянська академія, Український католицький університет, Київський політехнічний інститут імені Ігоря Сікорського та багато ін.), закликаючи науково-викладацький склад, аспірантів і працівників брати активну участь у реалізації ідей Відкритого доступу, розміщувати науково-дослідні роботи, науково-методичну та навчальну літературу, дисертаційні дослідження тощо в інституційних репозитаріях, інших відкритих електронних архівах; публікувати свої дослідження в наукових рецензованих журналах Відкритого доступу. Проте створення цифрового освітнього середовища наступного покоління (NGDLE) для підвищення ефективності вітчизняної освіти - це перспектива майбутнього.

Висновки. Аналіз зарубіжних наукових джерел довів, що на сьогодні в американській та європейській освітній практиці починає поширюватися нове покоління освітніх ресурсів, які утворюють цифрове навчальне середовище (NGDLE), виникаючи внаслідок еволюції традиційних систем управління навчанням (Learning Management Systems, LMS) та їхнє зближення з принципами відкритої освіти і гнучким персональним освітнім середовищем (Personal Learning Environment, PLE). Наразі цифрове освітнє середовище наступного покоління еволюціонує від вільного, але нечіткого набору інструментів і ресурсів, до надійного та потужного навчального середовища, яке зможе замінити наявні системи електронного навчання.

Цілком погоджуємося 3 позицією зарубіжних учених щодо складності й 
проблемності переходу до електронних навчальних засобів нової генерації, бо комбінування найсучасніших хмарних інструментів i нових протоколів, співіснування LMS i різноманітних інструментів у кожному курсі може призвести до технічно складного й перевантаженого середовища, вимагати надмірного часу для реалізації. До того ж нове покоління освітніх ресурсів вимагає переформатування принципів навчання та сформованої IКкомпетентності викладачів, які будуть заохочувати навчальні заклади до створення NGDLE - цифрового навчального середовища нового покоління.

\title{
СПИСОК ВИКОРИСТАНИХ ДЖЕРЕЛ
}

1. 7 Things You Should Know About NGDLE (2015). Retrieved from https://library.educause.edu/resources/2015/12/7-things-you-should-know-about-ngdle

2. Brown, M. (2017). The NGDLE: We Are the Architects. EDUCAUSE Review. (Pp. 1118). Retrieved from https://er.educause.edu/-/media/files/articles/2017/7/erm17411.pdf.

3. Dobbin, G. (2016). Exploring the Next Generation Digital Learning Environment: Opportunities and

Challenges.

Retrieved

from

https://library.educause.edu/resources/2016/6/exploring-the-next-generation-digital-learningenvironment-opportunities-and-challenges

4. Goodrum, D., Pfeifer-Luckett, R., Anderson, A., Leuba, M. .. \& \& Vervoort, C. (2019). 7 Things You Should Know About LTI Advantage. Retrieved from https://library.educause.edu/resources/2019/4/7-things-you-should-know-about-lti-advantage/

5. Green, C., Illowsky, B., Wiley, D., Ernst, D., \& Young, L. (2018). 7 Things You Should Know About Open Education: Content. Retrieved from https://library.educause.edu//media/files/library/2018/6/eli7157.pdf

6. Lynch, M. (2018). What is the Next Generation of Digital Learning Environments? Retrieved from_https://www.thetechedvocate.org/what-is-the-next-generation-of-digital-learningenvironments/

7. Moore, S. Breaking Down the Digital Learning Environment and NGDLE (n.d.). Retrieved from https://blog.extensionengine.com/next-generation-digital-learning-environment.

8. Wit, M., \& Dompseler, H. (2017). How to create a digital learning environment consisting of various components and acting as a whole? Retrieved from http://www.eunis.org/download/2017/EUNIS_2017_paper_16.pdf.

9. Згуровский, М. 3. \& Петренко, А. И. (2015). Цифровая наука в программе «Горизонт 2020». Системні дослідження та інформаційні технологіï, 1, 7-20.

10. Цифрові освітні ресурси. Інститут Новітніх Технологій в Освіті (б.д.). Взято 3 http://into-edu.com.ua/node/337.

\section{DIGITAL EDUCATIONAL RESOURCES IN THEORY AND PRACTICE OF MODERN FOREIGN EDUCATION}

\author{
Nadiia Voronova \\ $\mathrm{PhD}$ in Philosophy, Associate Professor \\ Culturology, Aesthetics and History Department \\ SHEI "Donbas State Pedagogical University" \\ Sloviansk, Ukraine \\ ORCID ID 0000-0001-7957-1655 \\ voronova.ns@ukr.net
}




\begin{abstract}
The processes of educational informatization at recent years are associated with its digitization. Mobile and other types of e-learning on digital devices are becoming more widespread. There is certain reformatting of electronic educational resources, and a new generation of educational resources - Digital Learning Resources (DLR) - is being developed. Now Open Digital Educational Resources are overridden because they can work on any digital device. The processes of digitization and openness gradually cover the whole educational environment. They are included in all educational stages and acquire normative and scientific substantiation. A lot of online courses have been developed for the higher education system. The opportunity of open access to video lectures by leading teachers from all over the world is provided. The electronic educational resources are currently being updated. Foreign science emphasizes the need to create a new generation of educational tools that will enter the digital learning environment.
\end{abstract}

The purpose of this article is to analyse the foreign scientific experience in the field of education digitalisation and to create a new generation of digital educational resources that operate in accordance with the principles of open education.

Foreign scholars working on the theoretical and practical provision of open education, digital and mobile technologies have recently spoken about a more recent generation of educational resources, which they call the Next Generation of Digital Learning Environment (NGDLE). NGDLE should become a universal digital learning platform for teachers and students, faculty and students, location and provision of programs, training services and training tools. The new generation of educational resources software will contain all the necessary components in one place and implement such functions as material presentation, testing, data management, schedules, analytics, multimedia, collaboration and communication tools, material exchange tools and training support. There are five key functions of NGDLE: interoperability and integration; personalization; analytics, advising, and learning assessment; collaboration; accessibility and universal design. Scientists have identified the main components and functional components of the next-generation digital education environment for higher education institutions.

It is proved that the new generation of educational resources is shaped by the evolution of traditional learning management systems (LMS) and their convergence with the principles of open education and the personal learning environment (PLE).

Key words: digital educational resources; next generation of digital learning environment; open education; open educational resources; open license.

\title{
REFERENCES
}

1. 7 Things You Should Know About NGDLE (2015). Retrieved from https://library.educause.edu/resources/2015/12/7-things-you-should-know-about-ngdle

2. Brown, M. (2017). The NGDLE: We Are the Architects. EDUCAUSE Review. (Pp. 11 - 18). Retrieved from https://er.educause.edu/-/media/files/articles/2017/7/erm17411.pdf.

3. Dobbin, G. (2016). Exploring the Next Generation Digital Learning Environment: Opportunities and Challenges. Retrieved from https://library.educause.edu/resources/2016/6/exploring-the-next-generation-digital-learningenvironment-opportunities-and-challenges

4. Goodrum, D., Pfeifer-Luckett, R., Anderson, A., Leuba, M. ... \& Vervoort, C. (2019). 7 Things You Should Know About LTI Advantage. Retrieved from https://library.educause.edu/resources/2019/4/7-things-you-should-know-about-lti-advantage/

5. Green, C., Illowsky, B., Wiley, D., Ernst, D., \& Young, L. (2018). 7 Things You Should Know About Open Education: Content. Retrieved from https://library.educause.edu//media/files/library/2018/6/eli7157.pdf 


\section{H. BOPOHOBA}

Цифрові освітні ресурси в теорії і практиці сучасної зарубіжної освіти

6. Lynch, M. (2018). What is the Next Generation of Digital Learning Environments? Retrieved from https://www.thetechedvocate.org/what-is-the-next-generation-of-digital-learningenvironments/

7. Moore, S. Breaking Down the Digital Learning Environment and NGDLE (n.d.). Retrieved from https://blog.extensionengine.com/next-generation-digital-learning-environment.

8. Wit, M., \& Dompseler, H. (2017). How to create a digital learning environment consisting of various components and acting as a whole? Retrieved from http://www.eunis.org/download/2017/EUNIS_2017_paper_16.pdf.

9. Zgurovskiy, M. Z. \& Petrenko, A. I. (2015). Digital Science in the Horizons 2020 Program. System research and information technology, 1, 7-20.

10. Digital Educational Resources. Institute of Advanced Technology in Education (n.d.). Retrieved from http://into-edu.com.ua/node/337.

Матеріали надійшли до редакції 26.04.2019 р. 